$12-1-2007$

\title{
Delarivier Manley's Possible Children by John Tilly
}

\author{
Rachel Carnell \\ Cleveland State University, r.carnell@csuohio.edu
}

Follow this and additional works at: https://engagedscholarship.csuohio.edu/cleng_facpub

Part of the Literature in English, British Isles Commons

How does access to this work benefit you? Let us know!

\section{Publisher's Statement}

This is a pre-copyedited, author-produced PDF of an article accepted for publication in Notes \& Queries following peer review. The version of record "Delarivier Manley's Possible Children by John Tilly." Notes and Queries (N\&Q) 2007 Dec; 54 (252) (4): 447-48. is available online at: http://nq.oxfordjournals.org/content/54/4/446.extract .

\section{Recommended Citation}

Carnell, Rachel, "Delarivier Manley's Possible Children by John Tilly" (2007). English Faculty Publications. 14.

https://engagedscholarship.csuohio.edu/cleng_facpub/14

This Article is brought to you for free and open access by the English Department at EngagedScholarship@CSU. It has been accepted for inclusion in English Faculty Publications by an authorized administrator of EngagedScholarship@CSU. For more information, please contact library.es@csuohio.edu. 


\section{DELARIVIER MANLEY'S POSSIBLE CHILDREN BY JOHN TILLY}

IT has long been known that Delarivier Manley had at least one child by her cousin and bigamous husband, the Tory MP John Manley. ${ }^{1}$ Scholars have not previously been aware, however, of archival evidence suggesting that she may also have had children from her relationship with John Tilly, Governor of Fleet Prison, a liaison that probably lasted from about 1697 until 1702, when Tilly married Margaret (née Reresby) Smith.

Manley herself acknowledges her relationship with Tilly (whose pseudonym is Cleander) in her fictional autobiography The Adventures of Rivella (1714): she explains that 'she was made the Town Talk by her scandalous Intriegue with Cleander'. ${ }^{2}$ She also observes that she 'tasted some years the pleasure of Retirement, in the Conversation of the person beloved' (51). In The New Atalantis (1709), Manley refers to herself as the 'airy Wife' of Tilly, whom she describes as 'a Gentleman very Ingenious'. ${ }^{3}$ In the same passage, she mentions that she offered important advice to Richard Steele (Monsieur Le Ingrate) while lying 'in Childbed' (117). These details suggest the possibility of a pregnancy by Tilly, since her lying-in for the birth of her son John Manley (b. 1691) would have happened long before she is believed to have met Steele or Tilly.

Two pieces of hitherto overlooked archival evidence also point to children by Tilly. A damaged and somewhat illegible document in the London Metropolitan Archives, from the Middlesex Sessions of the Peace for 1705, acknowledges that 'Dela Riviere Manly [sic] stands [missing word(s)?] indebted to $\mathrm{M}^{\mathrm{r}}$ George Haynes in $\mathrm{y}^{\mathrm{e}}$ sum of thirty pounds for Nursing her Children'. ${ }^{4}$ This paper, which was presumably signed by Haynes (although the portion with the signature is missing), reassigns to John Tilly the debt Manley owed

\footnotetext{
' John Manley, son of 'John and Dela Manley', was born on 24 June and christened on 13 July 1691, according to parish records for St Martin in the Fields, Westminster. This information is cited in the Dictionary of National Biography, s.v. Delarivier Manley.

2 The Selected Works of Delarivier Manley, ed. Rachel Carnell and Ruth Herman, 5 vols. (London, 2005), IV, 50.

${ }^{3}$ Selected Works of Delarivier Manley, II, 117.

${ }^{4}$ MJ SP $1705 / 10 / 4$.
} 
Haynes. In the document Haynes acknowledges that 'John Tilly Esq. has given out [missing word(s)] for the said thirty pounds'. The missing portion of this line presumably refers to either payment or security that Tilly promised for the debt. Haynes then asserts: 'I Doe therefore give over to the $\mathrm{s}^{\mathrm{d}} \mathrm{M}^{\mathrm{r}}$ Tilly all my Demands of this to $\mathrm{M}^{\mathrm{rs}}$ Manley \& Do promise to give [missing word(s)] to $\mathrm{M}^{\mathrm{r}}$ Tilly any sure[?] power[?] as he shall [illegible and possibly missing word(s)]... Enabling him to obtain $\mathrm{y}^{\mathrm{e}}$ same fr[om?] the $\mathrm{s}^{\mathrm{d}} \mathrm{M}^{\mathrm{rs}}$ Manley...' (ibid.). Although Haynes is assigning Tilly the legal power to be reimbursed by Manley, the fact that Tilly apparently took at least some temporary responsibility for this debt provides some circumstantial evidence of his paternity for the children being raised by Haynes.

Further circumstantial evidence for such children is offered by a document in Lady Cowper's Papers in the Hertfordshire Archives, which suggests that Manley may have had three children by Tilly. Lady Cowper would have had reason to resent Manley, since Manley had mercilessly satirized the Cowper family in The New Atalantis (1709) by recounting scandalous gossip about an alleged extramarital affair by Lady Cowper's husband, William Lord Cowper, Lord High Chancellor of Great Britain 1707-10, and about the murder trial of Spencer Cowper, William's brother, who was a suspect in the death of a young Quaker woman with whom he is believed to have had an affair. Despite Lady Cowper's probable bias against Manley, however, there may be some truth to her account of Manley's children.

In a note, not addressed to anyone, but simply dated 14 February (in a file of documents dated by the archive as being from 1714-18) Lady Cowper (i.e. Mary, née Clavering (1685-1724), William Cowper's second wife) relates what she heard about Manley, by way of explaining Manley's motives for maligning the Cowpers:

A Clergy man told me this

De la Riviere Manley Authoress of $\mathrm{y}^{\mathrm{e}}$ Atalantis was $y^{\mathrm{e}}$ Daughter of an apple woman in St. Andrews Holbourn [.] She gave herself $y^{\mathrm{e}}$ name for the beauty.
She married John Manley Esq, at $\mathrm{y}^{\mathrm{e}}$ time his first wife was alive in Cornwall (tho $\mathrm{y}^{\mathrm{e}}$ first was an old woman). She had a son by him. By $y^{\mathrm{e}}$ means of her husband she got acquainted with Tilly of $\mathrm{y}^{\mathrm{e}}$ fleet \& was privy to their clipping for $w^{\text {ch }}$ Manley would have hanged Tilly but that Tilly having taken her for his mistress by her kept Manley in awe, for by her means he could have hanged him for having 2 wives: She had 3 bastards by Tilly $\mathrm{w}^{\text {ch }}$ he put out to Nurse to a Fellow $\mathrm{y}^{\mathrm{t}}$ had outlived all his Creditors \& got out of $\mathrm{y}^{\mathrm{e}}$ fleet $\&$ they now are all 3 alive in a Cellar in fetter lane, they are 3 red haird boys $\& y^{\text {e }}$ man begs $w^{\text {th }} y^{\mathrm{m}}$. After Tilly she was kept by $y^{\mathrm{e}}$ Cook $y^{\mathrm{t}}$ Tilly had given her credit upon for $\mathrm{w}^{\mathrm{n}}$ she wanted to eat. $\mathrm{Y}^{\mathrm{e}}$ Cook sued Tilly in $\mathrm{y}^{\mathrm{e}} \mathrm{Ct}$ of $\mathrm{Ch}$ : for her board after he had left her \& had forbid $y^{\mathrm{e}}$ Cook to trust her. Mr Frances Cowper was Tillys Council \& $\mathrm{y}^{\mathrm{e}}$ Cook and Mrs. Manley were cast. $\mathrm{W}^{\mathrm{ch}}$ ws $\mathrm{y}^{\mathrm{e}}$ reason of her spight to $\mathrm{y}^{\mathrm{e}}$ family of $\mathrm{y}^{\mathrm{e}}$ Cowpers. $^{5}$

This note is inaccurate in its description of Manley's parentage: she in fact was the daughter of a royalist military officer (Sir Roger Manley) and his wife (MarieCatherine), a native of the Spanish Netherlands. ${ }^{6}$ Nor is Lady Cowper correct in her assertion that Manley took the name Delarivier 'for the beauty' of it; in fact, it was the name of the wife of one of her father's commanding officers. The description of Manley's first marriage to her bigamous first cousin may or may not be accurate, but it is clearly drawn from Manley's own account of it in The New Atalantis, in which Manley describes Ann Manley (née Grosse) as an 'old uneasie Lady'?

What truth there may be in the rest is difficult to ascertain. That 'children' are mentioned in the plural is consistent with the information in Haynes's reassignment of the $30 £$ debt, as is the detail about their nurse being male. Manley's being 'cast' at law by Tilly seems somewhat inconsistent with her generally positive depictions of him in Rivella.

\footnotetext{
5 DE P F211.

${ }^{6}$ Oxford Dictionary of National Biography, s.v. Manley.

7 Selected Works, II, 255.
} 
However, another document in the London Metropolitan Archives, indicates that in December of 1705 Manley was 'A Prisoner in the Fleet'. ${ }^{8}$ The note is short on legible details, but it refers to Manley having done something in November 'in Disregard of Her baile at the suit of our [illegible word]'. The 1705 imprisonment could possibly be related to the Chancery trial to which Lady Cowper's source is referring.

Whether or not Manley was ultimately cast at law by Tilly, it does seem reasonable to assume that she probably bore him several children during their four- to five-year liaison. Attempts at finding birth records for any such children fathered by Tilly, however, have thus far proved unsuccessful.

Cleveland State University

RACHEL CARNell

Post-print standardized by MSL Academic Endeavors, the imprint of the Michael Schwartz Library at Cleveland State University, 2015 